\title{
Financial Inclusion: Prospects and Challenges in the Nigerian Banking Sector
}

\author{
Abbas Umar Ibrahim, $\mathrm{PhD}^{*} \quad$ Aderonke Folashade Olasunkanmi \\ Department of Business Administration, Nile University of Nigeria, Jabi District, Abuja.Nigeria
}

\begin{abstract}
Financial inclusion has become a policy issue and a veritable tool for poverty reduction and the economic growth. This study aims to investigate how so far financial inclusion has benefited the banking sector and its challenges in Nigeria. Data for the study were collected mainly from secondary sources; such as Statistical Bulletins of the Central Bank of Nigeria (C.B.N.) and the National Bureau of Statistics. Data relates to the first and second elements of financial deepening (FDI and FD2), Liquidity ratio (LQR), Loan-to-deposit ratio (LDR), and Gross Domestic Product (GDP) covering a period from 1988 to 2017. The obtained data were analysed using the Ordinary Least Square (OLS) method facilitated with E-views 8 Econometric Software. The result showed that the first and second elements of financial deepening (FDI1 and FD2), and Liquidity ratio (LQR) all have a positive impact on the nation's economic growth whereas Loan-to-deposit ratio (LDR) does not. Assessment of the first element of financial deepening (FD1) is however insignificant. Also, the extent of the relationship between the dependent and independent variables is very good (about $96 \%$ ) although a case of autocorrelation is unavoidably present. Again the F- statistic shows a statistical significant relationship hence the null hypothesis is rejected. In conclusion, the study recommended the need to create deposit and borrowing windows at affordable cost to the poor and to the income group erstwhile tagged the 'not bankable', financial awareness should be well tailored in all local languages and across suitable platforms, among others.
\end{abstract}

Keywords: Financial Inclusion, Commercial banks, GDP, Liquidity Ratio, Loan-to-Deposit Ratio

DOI: $10.7176 / \mathrm{EJBM} / 11-20-06$

Publication date:July $31^{\text {st }} 2019$

\section{Introduction}

Financial inclusion is the practice that ensures the accessibility, availability and usage of formal financial system to all fragments of a population (Onaolapo, 2015). This is an important policy tool employed by governments in expediting efficient allocation of productive resources and stimulating growth in order to reduce poverty and significantly develop the day-to-day management of finances, as well as reduce the growth of informal sources of credit (such as money lenders), which are often found to be exploitative (Martinez, 2011). In contemporary times, the principle of financial inclusion serves as a major factor in economic growth. Access to financial services gives the poor the comfort of saving money reliably outside their wards, and reduces the risks that they face as a result of economic tremors. Hence, accessibility to financial services has increasingly become an area of interest for policymakers for the apparent reason that it has far reaching economic and social implications (Nwanne, 2015).

Due to the immense population of low-income earners, there is a reserve of the economy's idle fund usually held in small amounts. Access to financial services by these hundreds of millions of men and women (all over the world) who are presently excluded would provide the possibilities for the creation of a large depository of savings, investable funds, investment and therefore global wealth creation. This implies that, access to customized and bespoke financial services for low-income earners will promote enormous capital accumulation, credit creation and investment boom, which will provide a massive source of cheap long-term investable capital.

Financial inclusion has therefore become an explicit strategy for accelerated economic growth and is considered to be critical for achieving inclusive growth in a country. This realisation, in the recent past, was the major impetus for the adoption of policies and measures aimed at growing global financial inclusion as a means of promoting world economic prosperity.

The challenges of financial inclusion, according to Moghalu (2011) include; overall low level of financial literacy, double-digit inflation in the economy, increasing poverty, and uncompetitive wage levels. "Beyond the non-robustness and inefficiencies of the financial system which contributes to the act of being excluded or included, the more fundamental issue of suboptimal macroeconomic environment in the form of low income capacity and pervasive poverty level among the populace has played a more critical role of eroding the eligibility of the bulk of the financially excluded" (Moghalu, 2011).

Achieving a universal financial inclusion is a global challenge today with as much as 54.0 per cent of adults globally being financially excluded (with no access to financial services). The state in the developing economies is relatively poorer with some countries having as high as 70.0 per cent financial exclusion rate (Kama and Adigun, 2013). 


\subsection{Statement of Problem}

The evidence from literature have shown that globally, many countries have achieved high growth rates over the past decade, and many aspire to move with the tide, but the good performance has not dramatically translated into significant increase in micro financing and shared prosperity especially among the low income people. It is yet to deliver to low-income households and other vulnerable groups enough opportunities to improve their overall living standards. Similarly, in terms of economic indicators, the low-income population in Nigeria had been excluded from having easy access to financial services, especially in the rural areas where the general population has no access to basic source of livelihood including access to micro financing.

Despite modest overall achievements, there are still about 2.5 billion adults in the world without access to formal financial service (Dashi, Lahaya and Rizvanolli, 2013), and as such improving the global average level of financial inclusion has, therefore, become a global challenge (Moghalu, 2012). In the same vein, as World Bank (2014) puts it, about 23.8 percent of the 168 million population of Nigeria, between the ages of 15 years and above have accounts in formal financial institutions and less than 10 percent of them receive or send money via mobile phones.

From the foregoing, in order to navigate a path towards the financial inclusiveness for the entire population, this study provides a broad overview of the state of financial inclusion in Nigeria.

The above discussions together with the changing macroeconomic clime in Nigeria, this study will seek to fill the research gap on the relationship between financial inclusion and economic in Nigeria with relation to the banking system.

\subsection{Research Objectives}

The broad objective of this study is to examine the prospects and challenges of financial inclusion in Nigerian banking system. Other specific objectives are stated as follows:

i. Effect of financial inclusion on economic growth in Nigeria.

ii. To investigate the relationship between financial inclusion and economic growth.

\subsection{Research Questions}

The research questions are stated below:

i. What are the prospects and challenges of financial inclusion in Nigerian banking system?

ii. Is there a significant relationship between financial inclusion and banking system?

\subsection{Statement of Hypotheses}

The hypotheses tested are:

i. There is no significant effect of financial inclusion on economic growth in Nigeria

ii. There is no significant relationship between financial inclusion and the banking system in Nigeria

\section{Literature Review}

\subsection{Concept of Financial Inclusion}

Financial inclusion refers to all forms of initiatives that make formal financial services available, accessible and affordable to all sections of the population. Over time, a specific portions of the population have been exempted from the offerings of the formal financial sector either because of their level of income and volatility, gender, type of activity, location or level of financial literacy. There is therefore an urgent need to tap the untapped reserve of potentials of those individuals, groups and businesses that are currently excluded from the services and offerings of formal financial sectors, and explore them to develop their capacity, support their human and physical capital, enlighten them on the numerous income-generating activities, and manage risks associated with their livelihoods (Triki and Faye, 2013).

\section{Financial System Strategy 2020 (FSS2020)}

One of the critical initiatives in this direction was the incorporation of financial inclusion as one of the cardinal objectives of the Nigerian Financial System Strategy 2020 (FSS 2020). The FSS 2020 represents a holistic and strategic road map and framework for developing the Nigerian financial sector into a growth catalyst that will enable Nigeria be one of the 20 largest economies by 2020. The Financial System Strategy (FSS2020) identified six stakeholders within the financial sector. These were the providers of financial services, which are regarded as the suppliers in the value-chain of financial inclusion. The group included the banking institutions, non-bank financial institutions, insurance companies, capital market players, pension institutions, and technology providers together with their regulatory bodies, all important to the process of financial inclusion.

Of the six initiatives adopted to strengthen the domestic financial market, four directly address financial inclusion. These initiatives include:

- Development of varied financial products;

- Enhancement of payment processes; 
- Development of credit system; and

- Encouragement of a savings culture

The strategy highlighted the objectives of financial inclusion as the state in which adults (persons above the age of 18) have formal easy access to a broad range of financial products, which are appropriate, provided at affordable cost and with dignity for the clients.

To provide easy access means to reach and be reached by the unbanked at any time and also to operate in such a way that any desiring customer can easily access the institution and the services therein. The step was to ensure that the procedures for accessing the services of financial institutions services were simple and seamless. In order to give a more robust definition of financial inclusion, Alliance for Financial Inclusion (AFI, 2011) highlights the different concepts related to financial inclusion, which are: access (making financial services available and affordable to users), usage (making customers use financial services frequently and easily) and quality (making financial services customized for clients' needs).

\section{Challenges of Financial Inclusion}

Anecdotal suggestion has revealed that about 46 per cent of the world adults have access to financial services. According to (Moghalu, 2011), the shortage of access to financial services by billions of adults all over the world poses serious challenges to global economic growth and development. He noted that the major issues within the general economic conditions have manifested as discussed:

i. A major challenge in the deployment and coverage of financial inclusion process is how to ensure that the poor and low income rural dwellers are duly informed considering the lack of general enlightenment among this segment of the Nigerian society. The vast majority of the financially excluded 40 million Nigerians lack the basic knowledge of the services and benefits derivable from accessing formal financial services. Financial literacy at its lowest ebb has remained a major impediment to the progress of the financial inclusion.

ii. Another challenge is the inability of the populace to save due to the double digit inflation in the economy, with its attendant effects on real interest rate and continuous loss of money value. The disincentive negative real interest rates is obviously discouraging potential savers from saving and thereby shutting them out in the uncertain tides of other non-bank saving schemes.

iii. Even though the economy has been reported to have improved at an average of 7.0 per cent between 2009 and 2011, the rate of poverty seems not to have reduced as the progress of most of the poverty-reducing Millennium Development Goals has been very slow.

iv. The uncompetitive wage levels in the public sector where the low income earners and groups are predominant in number are rather excluded financially. Though salaries are paid into their bank account, but personnel only use the bank for financial bookkeeping and collection purposes alone, with little or nothing to save.

\section{Prospects of financial inclusion}

Although the Central Bank of Nigeria has been implementing various policies and processes to enhance financial inclusion in the country, there still exist gaps which must be bridged in order for the excluded to be included. The inability of a large portion of the financially excluded populace to meet the basic Know Your Customer (KYC) requirement and absence of unique Identification data management system remain one of the systemic challenges for high financial inclusion rate to be attained. However, KYC process have been receiving a lot of fine-tuning by the Bank through the tiered approach and other considerations which aims at easing some of the stringent requirements of the KYC procedures for the low-income financially excluded to be included. In other the reduce the stringency of the KYC process, deposit money banks have now been mandated to accept the Voters card as a valid means of identification for account opening

It is also of great concern that the various electronic channel platforms such as ATM, POS and mobile banking platforms have not performed optimally as they should. E-channel requests and services are at best delayed or experience incessant downtimes more often than not where low-income groups are dominated. However, the end to end deployments of technologies into the financial sector is gradually making it possible to open an account, request for ATM card, deposit funds and withdraw funds without actually queuing in our financial institutions today.

It is very compelling, that the mass retail market, with the monthly income of between $\mathrm{N} 6,000$ to $\mathrm{N} 40,000$ have a combined monthly income of N590 billion, compared with N570 billion monthly income for all other income groups. Capturing this segment into the financial system will not only offer enormous amount of cheap investible funds but also will go a long way to be a game-changer in the nation's financial system with increased availability of credit at lower cost.

\subsection{Theoretical Framework}

\section{Financial Intermediation Theory}

According to the modern theory of financial intermediation also referred to as asymmetric information theory, an 
important role of banks in the economy is to create liquidity by funding illiquid loans with liquid demand deposits (Diamond, 1984; Ramakrishna and Thakur, 1984). However, formal financial institutions did not usually cater for low income and poor households because they were perceived to be unable to save and seen as too risky to lend money to. On the savings side, low income and poor households were considered to be unable to save by definition: the poor cannot save precisely because they are too poor and therefore do not have extra cash. In contrast to this, according to Subbargo (2009) financial inclusion offers an avenue for bringing the savings of the poor into the formal financial intermediation system and channels it to investment, which further increased the financial inclusion.

On the lending side, traditional commercial banks (and the formal financial sector in general) typically had no interest in lending to low income earners because of their lack of feasible collateral and the high transaction costs associated with the small loans that are well matched to them (Diagne and Zeller, 2001). However, a large body of literature work has shown that the poor experiences in accessing the credit market are due to informational asymmetries (Beck, Demirguckunt and Maksimovic 2002).

When cross examining rural credit markets, Hoff and Stiglitz (1990) identify three important problems that aroused from asymmetric information from the lender's point of view that make the rural credit markets behave the way they do: the screening problem, the incentives problem and the enforcement problem. The screening problem (or adverse selection problem) refers to the fact that borrowers differ in the likelihood that they will default and it is costly to determine the degree of that risk for each borrower; that is, it is costly to obtain information about the character of loan applicants. The incentives problem (or moral hazard problem) refers to the fact that it is costly to ensure that borrowers take those steps, which make repayment most likely. The third problem is the enforcement problem (or willingness to pay problem) and refers to the fact that it is difficult to force repayment, that is, it is difficult to implement mechanisms to increase the chance of repayment by individuals who are able to do so.

\subsection{Empirical Review}

Several scholars and researchers have reviewed the concept of financial inclusion and economic growth. Okpara (2011) carried out the causality test on financial inclusion and financial stability in Nigeria. The empirical investigation was conducted using Toda Yamamoto causality test and also, the long-run relationship between financial inclusion and financial stability is ascertained using Johanson Cointegration test. The empirical findings demonstrate a strong evidence of one-way direction causality running from financial inclusion to financial stability and also indicate a long-run relationship between the two variables.

In addition to Ardic et al. (20011), Demirguc-Kunt and Klapper (2013) investigated the variation in the use of financial services across and within 148 Countries. The field study survey data used show that 50 percent of adults worldwide have an account at a formal financial institution, but account penetration varies from countries to countries by level of economic development and across income groups within countries. They also established that the majority of borrowing by adults in developing countries is from informal sources, while 12 percent of account holders save money using informal methods. The use of informal, group-based saving methods (such as rotating savings clubs) is also very common, particularly in sub-Saharan African countries such as Cameroon, Kenya, and Nigeria.

Efobia Beecrofta and Osabuohien (2014), used data from the World Bank Household Survey (2011) on financial inclusion to examine the access to, and use of bank services in Nigeria. They engaged logistic regression based on the marginal effect to estimate the relationships between dependent and independent variables. They also used the Tobit regression estimation technique as further estimation checks to deal with cases of truncated explanatory variables. Their findings showed that the attributes, income level, age and individuals' knack for ICT have an effect on the access to and use of bank services in Nigeria.

Aduda and Kalunda (2012) carried out a study on financial Inclusion and financial sector stability and established that the existing studies had shown that the genesis of financial exclusion is social exclusion which indicates the depth and importance of financial inclusion in creating inclusive development. Ardic, Mylenko and Saltane (2011) conducted a cross country analysis with a new data set using econometric analysis. The results of their study confirm the earlier findings in the literature that higher deposit and/or loan correlation is associated with higher economic and financial development as measured by GDP per capita. Furthermore, their findings indicate that 56 percent of adults worldwide are unbanked, although the numbers differ across high-income and developing countries (17 percent and 64 percent, respectively).

Kama and Adigun (2013) reviewed experiences of other authorities in the achievement of financial inclusion. It further studied past and present efforts at promoting financial inclusion in Nigeria. And asserted that although gradual progress is being made to improve on financial inclusion, critical issues like low financial literacy, inadequate infrastructural facilities as well as inadequate and unstable technology based facilities by financial institutions, has limited the achievement and significant expansion in the level of financial inclusion in Nigeria. Ogbeide (2019) examined the effects of CBN's cashless policy on financial inclusion in the Nigerian emerging 
economy and show that the cashless policy had a major effect in increasing customers' deposits in commercial banks of Nigeria. The volume of Automated Teller Machine (ATMVL) and Volume of Point of Sales (POSVL) shows more significant and positive influence on financial inclusion in urban area than the rural area. However, Web Based Technique (WBTVL) reveals a non-significant effect on financial inclusion both in urban and rural centres.

There are few studies that have analysed the prospects and challenges of financial inclusion, which necessitates the gaps for investigation in this study.

\section{Methodology}

The study employed secondary data obtained from annual reports for the period of thirty-year period from 1988 to 2017. Data were obtained from the Statistical Bulletin of the Central Bank of Nigeria (CBN), and the Annual Abstract of the National Bureau of Statistics (NBS). There are different financial inclusion variables as literature suggests. These include, but not limited to number of bank branches per 10,000 $\mathrm{km}^{2}$, number of Automated Teller Machines (ATMs) per 10,000 $\mathrm{km}^{2}$, access to credit, and number of bank accounts held by a particular segment of the economy, and elements of financial intermediation. The choice of the variables however is inhibited by paucity of data for Nigeria. Hence, the study takes two measures of financial inclusion: the narrow measure and the broad measure.

\section{Model Specification}

The econometric model was used in this research. The mathematical and stochastic model of this research is indicated below:

Where;

$$
G D P=\beta_{0}+\beta_{1} F D 1+\beta_{2} F D 2+\beta_{3} L D R+\beta_{4} L Q R T+\mu_{t}
$$

GDP $=$ Gross Domestic Product (proxy for economic growth),

FD1 $=$ the ratio of Broad Money to GDP (M2/GDP),

FD2 $=$ the ratio of Credit to Private Sector to GDP (CPS/GDP).

LDR $=$ loan-to-deposit ratio and

$\mathrm{LQR}=$ Liquidity ratio (LQR) of commercial banks.

Economic growth refers to sustained rise in the value of economic activities within a country over a period of time. The Gross Domestic Product (GDP) often comes in handy in measuring the aggregate worth of an economy. In like manner, the model incorporates a broader view of financial inclusion by employing two financial deepening indicators (FD1 and FD2). FD1 represents the ratio of Broad Money to GDP (M2/GDP), while FD2 is the ratio of Credit to Private Sector to GDP (CPS/GDP). According to Nwagwugwu (2008) financial deepening refers to the increase provision of financial services with a wider choice of services geared towards the development of all levels of society. The World Bank (1992) further notes that financial deepening encompasses increase in the stock of financial assets.

From this perceptive, financial deepening implies the ability of financial institutions in general to effectively mobilize financial resources for growth and development. This is affirmed in Okeke (2009) which observes that a high level of financial deepening is a necessary condition for accelerating growth in an economy.

Additionally, the model includes other important financial ratios as loan-to-deposit ratio (LDR) and Liquidity ratio (LQR) of commercial banks. The justification is that a financial system with good or rising LDR and LQR is indicative of an expanded platform for financial inclusion. Generally, this model is an improvement from Ighodaro and Oriakhi (2011) which defines financial development in terms of Loan-to-Deposit ratio and Broad Money income only.

The justification is that a financial system with good or rising LDR and LQR is indicative of an expanded platform for financial inclusion.

\section{Data Analysis \\ 4.1 Data Presentation}

The Table 4.1 below present the data on gross domestic product (GDP), financial deepening (FD1 and FD2), ratio of Credit to Private Sector to GDP (CPS/GDP) and Liquidity ratio (LQR) of commercial banks, 1988-2017 
Table 4.1: Data on gross domestic product (GDP), financial deepening (FD1 and FD2), ratio of Credit to Private Sector to GDP (CPS/GDP) and Liquidity ratio (LQR) of commercial banks, 1988-2017

\begin{tabular}{|c|c|c|c|c|c|}
\hline YEAR & FDI1 & FDI2 & LDR & LQRT & GDP \\
\hline 1988 & 0.56 & 9.80 & 38.67 & 23.663 & 12.2045 \\
\hline 1989 & 0.46 & 9.95 & 30.89 & 23.044 & 12.13134 \\
\hline 1990 & 0.57 & 10.06 & 27.28 & 21.628 & 12.12031 \\
\hline 1991 & 0.6 & 10.18 & 27.66 & 20.821 & 12.21124 \\
\hline 1992 & 1.02 & 10.22 & 21.87 & 26.465 & 12.23549 \\
\hline 1993 & 2.29 & 10.42 & 45.83 & 20.806 & 12.39193 \\
\hline 1994 & 1.2 & 10.72 & 37.46 & 18.314 & 12.30082 \\
\hline 1995 & 6.24 & 10.76 & 40.97 & 13.674 & 12.37467 \\
\hline 1996 & 1.81 & 11.14 & 58.16 & 13.245 & 12.37467 \\
\hline 1997 & 2.15 & 11.38 & 67.61 & 13.481 & 12.48891 \\
\hline 1998 & 2.65 & 11.77 & 65.48 & 15.013 & 12.51122 \\
\hline 1999 & 4.28 & 12.20 & 56.21 & 13.969 & 12.52392 \\
\hline 2000 & 2.43 & 12.49 & 40.99 & 16.78 & 12.52616 \\
\hline 2001 & 3.87 & 12.67 & 80.24 & 10.933 & 12.54756 \\
\hline 2002 & 4.06 & 12.82 & 69.27 & 9.643 & 12.59047 \\
\hline 2003 & 3.89 & 12.97 & 74.49 & 11.403 & 12.61826 \\
\hline 2004 & 2.92 & 13.17 & 58.68 & 13.756 & 12.64719 \\
\hline 2005 & 2.91 & 13.46 & 64.23 & 14.252 & 12.65135 \\
\hline 2006 & 2.39 & 13.85 & 63.96 & 13.007 & 12.70436 \\
\hline 2007 & 2.39 & 14.09 & 68.28 & 18.095 & 12.79106 \\
\hline 2008 & 3.93 & 14.29 & 47.12 & 13.827 & 12.97896 \\
\hline 2009 & 2.96 & 14.50 & 60.89 & 14.281 & 13.07639 \\
\hline 2010 & 2.13 & 14.63 & 57.75 & 13.447 & 13.17605 \\
\hline 2011 & 4.44 & 14.85 & 60.74 & 13.775 & 13.23914 \\
\hline 2012 & 3.31 & 15.21 & 44.61 & 14.279 & 13.2977 \\
\hline 2013 & 3.64 & 15.58 & 64.32 & 24.479 & 13.3602 \\
\hline 2014 & 3.96 & 16.03 & 61.04 & 33.172 & 13.4223 \\
\hline 2015 & 5.08 & 16.19 & 63.98 & 41.299 & 13.48276 \\
\hline 2016 & 3.12 & 16.38 & 73.36 & 54.8 & 13.4944 \\
\hline 2017 & 4.56 & 16.41 & 73.44 & 55.55 & 13.532 \\
\hline
\end{tabular}

Source: Statistical Bulletin, CBN (Various issues); Author's Computations

\section{Findings and Discussion}

The data presented in Table 4.1 was analysed using Multiple Regression Analysis with E-views 8.0. The result is presented below:

Dependent Variable: GDP

Method: Least Squares

Date: 06/07/19 Time: 09:47

Sample: 19882017

Included observations: 30

\begin{tabular}{rrrrr}
\hline \multicolumn{1}{c}{ Variable } & Coefficient & \multicolumn{1}{c}{ Std. Error } & t-Statistic & Prob. \\
\hline C & 10.14434 & 0.115523 & 87.81233 & 0.0000 \\
FDI & 0.016988 & 0.016134 & 1.052959 & 0.3024 \\
FDI2 & 0.202788 & 0.013249 & 15.30636 & 0.0000 \\
LDR & -0.002936 & 0.001568 & -1.872323 & 0.0729 \\
LQRT & 0.003812 & 0.001740 & 2.190436 & 0.0380 \\
\hline \hline R-squared & 0.962253 & Mean dependent var & 12.73351 \\
Adjusted R-squared & 0.956214 & S.D. dependent var & 0.453958 \\
S.E. of regression & 0.094992 & Akaike info criterion & -1.719046 \\
Sum squared resid & 0.225585 & Schwarz criterion & -1.485513 \\
Log likelihood & 30.78569 & Hannan-Quinn criter. & -1.644337 \\
F-statistic & 159.3267 & Durbin-Watson stat & 0.735112 \\
Prob(F-statistic) & 0.000000 & & \\
\hline \hline
\end{tabular}


The result showed that the first and second elements of financial deepening (FDI1 and FD2), and Liquidity ratio (LQR) all have a positive impact on the nation's economic growth whereas Loan-to- deposit ratio (LDR) does not. Estimate of the first element of financial deepening (FD1) is however insignificant. Also, the extent of the relationship between the dependent and independent variables is very good (about $96 \%$ ) although a case of autocorrelation is unavoidably present. Again the F-statistic shows a statistical significant relationship result hence the null hypothesis is rejected.

The study indicates that there about $96 \%$ of the total variations in economic growth are explained by the variations in first and second elements of financial deepening, liquidity ratio and loan-to-deposit ratio. The study also revealed that all the financial inclusions variables used collectively have effect on economic growth.

\section{Discussion}

This study has examined the effects of financial inclusion on the Nigerian economic growth; findings from the empirical results indicate relationship between financial inclusions in Nigeria, economic growth over the thirty (30) years period of study. Empirical finding that examines the relationship between financial inclusion and economic growth in Nigeria also indicates that there is a significant relationship between financial inclusion and economic growth in Nigeria in the period under study (giving Prob. (F-Stat) is 0.000000 as against F-Stat 159.3267).

The finding suggests that financial inclusion will have a positive significant impact on the economic growth of Nigeria. This study agrees with the findings of Aduda and Kalunda (2012) which showed that the genesis of financial exclusion is social exclusion which indicates the depth and importance of financial inclusion in creating inclusive development. Also, Ardic, et al. (2011) affirm that higher deposit and/or loan correlation is associated with higher economic and financial development as measured by GDP per capita, which is also supported by Okpara (2011), whose study demonstrated a strong evidence of one-way direction causality running from financial inclusion to financial stability and also indicate a long-run relationship between the two variables.

However, the study does have some limitations. It has only examined the relationship between financial inclusions on Nigerian economic growth; emphasis on which components of financial inclusion like lending; means of payment and investment window has been minimal thus providing a good basis for future studies to examine this matter in greater detail. This study also gives a signal to the financial regulator on the need to put suitable policies or regulations in place that will encourage financial intermediation among the rural people.

\section{Conclusion}

Economic growth is influenced largely by equal sharing of benefits and opportunities, of which financial inclusion is just one of such opportunities that must be fairly distributed in the country in order to realize inclusive growth. Undoubtedly, issues overwhelming financial inclusion such as financial literacy and awareness continued to remain a matter of concern with regard to usage of financial services or products. This therefore calls for a concerted effort by all the stakeholders such as banks, governments, civil societies, and NGOs etc. to put heads to achieving the objective of financial inclusion. Unquestionably, the issue of enlarging the geographical and demographic reach creates challenges from the viability or sustainability perspectives and suitable business models are still developing and various delivery mechanisms are being tested with by the numerous government agencies at the central \& state level. But, it is felt that the efforts taken are not good enough to meet this overwhelming issue of Financial Inclusion. Financial Literacy and Awareness appeals for harmonization of all the participants likeBanks, Governments, Civil Societies, and NGOs etc. to reach the objective of Financial Inclusion.

\section{Recommendations}

Based on the empirical findings drawn from the study, it shows that in order to strengthen and sustain prospect of financial inclusion, while equally reducing its challenges, the study recommends

i. The need to create deposit and borrowing windows at affordable cost to the poor and to the income group erstwhile tagged the 'not bankable', financial awareness should be well tailored in all local languages and across suitable platforms.

ii. Strengthening of Microfinance Institutions which can give easy access to banking services to the grassroots and unbanked also increase in the number of rural bank outlets and cash centers to cater for the financial needs of the excluded populace.

\section{References}

Andrianaivo, M and Kpodar, K (2011): "ICT, Financial Inclusion, and Growth: Evidence from African Countries" IMF Working Paper WP/11/73.

Ardic, O.; Mylenko, N. and Saltane, V. (2011). Small and Medium Enterprises a Cross-Country Analysis with a New Data Set, The World Bank, Policy Research Working Paper 5538.

Becks, T.; Demirguc-kunt, A. and Maksimovic, V. (2002). "Financial and Legal Constraint to Firm Growth: Does Size Matter," World Bank mimeo. 
Brown, M.; Guin, B and Kirschenmann, K. (2013). Microfinance Banks and Financial Inclusion, the 3rd European Research Conference on Microfinance, Zurich.

Dashi, E.; Lahaya, E.; and Rizvanolli, R. (2013). Trends in International Funding for Financial Inclusion. Consultative Group to Assist the Poor Brief. December.

Demirguc-Kunt, A. and Leora Klapper. L. (2012). "Measuring Financial Inclusion: The Global Findex Database." Policy Research Working Paper 6025, World Bank, Washington, DC.

Diagne, A. and Zeller, M. (2001). Access to Credit and its Impact on Welfare in Malawi Research Report 116. Washington D.C.: IFPRI.

Diamond, D. (1984). "Financial Intermediation and delegated monitoring", Review of Economic Studies, 51(3): 393-414.

Efobia, U.; Beecrofta, I.and Osabuohien, E. (2014). Access to and use of bank services in Nigeria: Microeconometric evidence, Review of Development Finance 4: 104-114.

Hoff, K. and Stiglitz, J.E. (1990). Introduction: Imperfect Information and Rural Credit Markets-Puzzles and Policy Perspectives. The World Bank Economic Review, 4 (3): 235-250.

Ighodaro C. and Oriakhi.D. (2011). Trivanite Causality Relationship between Financial Development and Economics Growth in Nigeria, Journal of Banking, Chartered Institute of Bankers of Nigeria, 5(1).

Kama, U. and Adigun, M. (2013), Financial Inclusion in Nigeria: Issues and Challenges, Occasional Paper No. 45 , Central Bank of Nigeria, Abuja.

Martinez M.V. (2011) The Political Economy of Increased Financial Access. A Thesis Submitted in Partial Fulfilment of the Requirement for The Degree of Master of Public Policy to the Faculty of the Graduate School of Arts and Sciences of Georgetown University.

Mbutor, M.O. and Uba, I.A. (2013). The impact of financial inclusion on monetary policy in Nigeria, Journal of Economics and International Finance. 5(8): 318-326

Moghalu K. C. (2012), “The challenge of financial inclusion: The Nigerian perspective” Being text of remarks at the 2011 global policy forum of the Alliance for Financial Inclusion (AFI) at Riviera Maya, Mexico on September 28, 2011.

Nwagwugwu, A. A. (2008), "Reflection on the Possibilities of Reduction in Poverty in the Context of Economic Growth and Underdevelopment, Democracy and Good Governance", Development Policy Management and Network Bulletin, 9(1), 36-40.

Nwankwo, O. and Nwankwo, O.N.O. (2014). Sustainability of Financial Inclusion to Rural Dwellers in Nigeria: Problems and Way Forward. Research Journal of Finance and Accounting, 5(5): 24-31.

Nwanne, T. F. I. (2015). Relationship between Financial Inclusion and Economic Growth in Nigerian Rural Dwellers, International Journal of Small Business and Entrepreneurship Research, 3(7): 17-27

Ogbeide, S.O. (2019), Empirical assessment of the effects of cashless policy on financial inclusion in the Nigerian emerging economy, Accounting, 5: 61-68

Okeke. F. 0. (2009). Financial Inclusion: An Instrument for Economic Growth and Balanced Development in Rural Areas. Journal of the Chartered Institute of Bankers of Nigeria, 6(8): 38-45.

Okpara, G. C. (2011). Financial Inclusion and Financial Stability: A Toda-Yamamoto Causality Approach, ABSU Journal of Arts, Management, Education, Law and Social Sciences (Jamelss), 1(1): 86-100.

Onaolapo A. R. (2015). Effects of Financial Inclusion On the Economic Growth of Nigeria (1982-2012), International Journal of Business and Management Review, 3(8): 11-28

Ramakrishnan, R.T.S. and Anjan Thakor (1984), "Information Reliability and a Theory of Financial Intermediation," Review of Economic Studies 51: 415-432.

Serrao, M. V.; Sequeira, A. H. and Varambally, K. V. M. (2013). Conceptual Framework to Investigate the Accessibility and Impact of Financial Inclusion. Indian Journal of Research. 2 (9): 47-49.

Subbarao, D. (2009). Financial inclusion: challenges and opportunities. Being a presentation by Dr Duvvuri Subbarao, Governor, Reserve Bank of India, at the Bankers' Club, Kolkata on December 9, 2009.

Triki, T. and Faye, I. (2013). Financial Inclusion in Africa. African Development Bank Research Department, 15, Avenue du Ghana, Angle des rues Pierre de Coubertin et Hedi Nouira, Tunis Belvedere, Tunisia. ISBN: 9789938-882-19-3.

World Bank (2014). Global Financial Development Report 2014. Washington, DC: World Bank. 